\title{
Nature and Symbol Through Useable Approach in The Novel Harga Sebuah Maruah
}

Nadia binti Ishak, Kamariah binti Kamarudin, Norazlina Mohd. Kiram \& Haliza Abdul Rahman

To Link this Article: http://dx.doi.org/10.6007/IJARBSS/v11-i19/11735

DOI:10.6007/IJARBSS/v11-i19/11735

Received: 20 October 2021, Revised: 22 November 2021, Accepted: 08 December 2021

Published Online: 25 December 2021

In-Text Citation: (Ishak et al., 2021)

To Cite this Article: Ishak, N. binti, Kamarudin, K. binti, Kiram, N. M., \& Rahman, H. A. (2021). Nature and Symbol Through Useable Approach in The Novel Harga Sebuah Maruah. International Journal of Academic Research in Business and Social Sciences, 11(19), 264-274.

Copyright: (c) 2021 The Author(s)

Published by Human Resource Management Academic Research Society (www.hrmars.com)

This article is published under the Creative Commons Attribution (CC BY 4.0) license. Anyone may reproduce, distribute, translate and create derivative works of this article (for both commercial and non-commercial purposes), subject to full attribution to the original publication and authors. The full terms of this license may be seen

at: http://creativecommons.org/licences/by/4.0/legalcode

Special Issue Title: Youth and Community Wellness, 2021, Pg. 264 - 274

http://hrmars.com/index.php/pages/detail/IJARBSS

JOURNAL HOMEPAGE

Full Terms \& Conditions of access and use can be found at http://hrmars.com/index.php/pages/detail/publication-ethics 


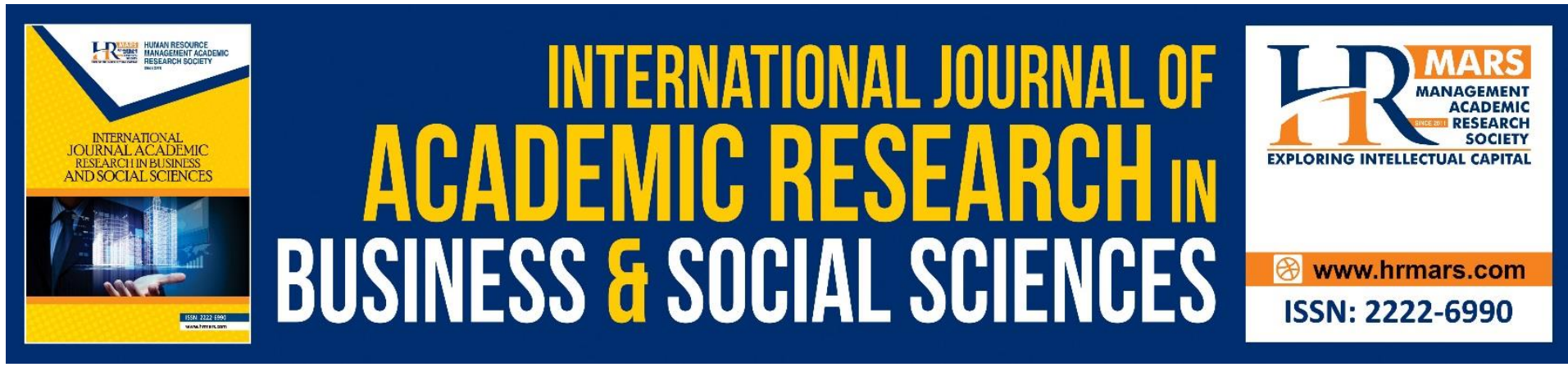

\title{
Nature and Symbol Through Useable Approach in The Novel Harga Sebuah Maruah
}

\author{
Nadia binti Ishak ${ }^{1,2}$, Kamariah binti Kamarudin ${ }^{1,2}$, \\ Norazlina Mohd. Kiram ${ }^{1,2} \&$ Haliza Abdul Rahman ${ }^{1,2}$ \\ ${ }^{1}$ Institute for Social Science Studies, Universiti Putra Malaysia, 43400 Serdang, Selangor, \\ Malaysia, ${ }^{2}$ Faculty of Modern Languages and Communication, Universiti Putra Malaysia, \\ Serdang, Selangor \\ Email: kkamaria@upm.edu.my
}

\begin{abstract}
Since centuries ago, the Malay community is synonym with nature that has a bonding tie. The nature becomes part of the lives for the Malay community and both rely on each other for living. Thus, this bonding makes the Malay community very sensitive towards the surrounding, incident or event that happens. In this context the Malay community will immediately reacts and connect towards whatever is happening in nature as an exemplary on their daily lives. Therefore, this article is to show that element of nature as a symbol in describing something meaningful or things. This research is based on the novel of Harga Sebuah Maruah (2007) authored by Azizi Haji Abdullah. This journal uses Usable Approach which is in the theory of Pengkaedahan Melayu as an analysing framework. It points on literature as a nature object which events has its course and functions in a way to benefits in the daily living of mankind. The theory of Pengkaedahan Melayu generated by Hashim Awang emphasizes on the way of live, believe and culture of the Islam community. This research shows that Usable Approach is appropriate to be absorbed in this research in showing that element of nature as a symbol in describing something meaningful or things by using the principle which is in the Usable Approach.
\end{abstract}

Keywords: Nature, Symbol, Approach, Usable, Novel, Community, Malay

\section{Introduction}

Nature is an element that bonds tightly with mankind. According to Kamus Dewan Fourth Edition (2014) alam means everything in the sky and on earth (earth, stars, power source and so on). According to (Awang, 2003) describing that nature characterises a whole of earth, sky and ocean which depends on each other. This entire element completes each other and missing one element would be an incomplete in mankind living. Meanwhile, according to (Fok, 2008) nature is everything in the sky and on earth. Nature is evidence of the Almighty Creator to fulfil the needs of human in living. By such, based on some understanding of the above, it is concluded that nature is an element of in the sky and earth including air, water, animals and forest that provides living source to mankind. 
Besides, the dependency of human and nature is a relationship that cannot be denied of its importance. Mankind fully depends on nature to carry on their daily living in the aspect of source of food, water and the tie of ecosystem. Therefore, the existence of relationship is strong with nature making humans sensitive towards whatever is happening in their surroundings. Foremost, nature is created by Allah SWT which is also written in the al-Quran through surah Al-Baqarah verse of 164 which means:

" (To guide) those who use their reason (to this Truth) there are many Signs in the structure of the heavens and the earth, in the constant alternation of night and day, in the vessels which speed across the sea carrying goods that are of profit to people, in the water which Allah sends down from the sky and thereby quickens the earth after it was dead, and disperse over it all manner of animals, and in the changing courses of the winds and the clouds pressed into service between heaven and earth".

(Mushaf Tajwid with the translation to Malay, 2006: 315)

Ibn Katsir (Basmeih, 2006) gives an interpretation as the above in saying that the creation of nature is and as a sign of power of the Almighty and proves the greatness as a Creator. Also, the following word explains that the creation of sky and earth by Allah SWT needs to be contemplation for Islam to realise the power of Almighty in making the nature complete for daily living of human on this earth. In other words, nature is a part of daily living for mankind and bonds with the soul of human (Jaafar, 2017). In this context, author uses nature as an element of medium in conveying something that needs to be shown to the community. This interpretation interprets through constitution to reveal the authors thought in describing something meaningful or things. Next, this interpretation is made into guide, teaching and exemplary to daily living for mankind.

\section{Theory and Research Methodology}

This analysis uses Useable Approach which is one of the approaches through Universe Methodology in the theory of Pengkaedahan Melayu which is trigged by Hashim Awang. This theory is an observation by Hashim Awang in year 1989 on living, believe and the Malay community culture. Hashim Awang build this theory based on the lives, surrounding and culture of the Malay community. Moreover, theory of Pengkaedahan Melayu is based on kitab Tajul Muluk which describes the procedures and living of Islam. Theory of Pengkaedahan Melayu is paired tightly of Islam and nature. Thus, the theory of Pengkaedahan Melayu is a theory of impact of Islam and it's believed. Through theory of Pengkaedahan Melayu, (Awang, 2003) divides into two which is Universe Methodology and Religion Methodology. Both this has its own stand which is known as approach. Universe Methodology is from Useable Approach, Morale Approach and Prediction Approach. While, Religion Methodology consist of Preaching Approach, Community Approach and Art Approach.

Useable Approach shows that literature is an object or creation from nature which benefits and useful towards living for mankind. Literature and nature in this context dependable with each other. According to (Awang, 1998) Useable Approach emphasises and focuses towards the literature benefit that implies on the welfare of living for human. Literature that benefits is shown to public and is valued in an out of its aspect. Furthermore, according to (Fok, 2008) interpretation in a form of useful literature and nature is based on 
the perception of assessing and interpreting. This can be assumed if the reader gets impress by the literature, the reader will get the benefits from the literature one is reading. Other than that, every element on this earth has its own benefit and importance towards mankind. Aligning to that, literature is seen to have its own similar approach which is literature as a nature object that cans benefits and gives goodness towards mankind. Also, literature is known as a nature incident but it's distinguish is the creator only; the object nature is created by Allah SWT, for literature is created by human.

Summatively, this research searches on how far strength and effective the nature element as symbol to explain a meaning or incident by using the theory of Pengkaedahan Melayu through

Useable Approach. Through this research, the researcher will be able to analysis few of nature element by referring to "View of Nature Element as Symbol" as the symbolic introduced by (Fok, 2008). According to (Fok, 2008) the "View of Nature Element as Symbol" of exploitation by author as the background is also the role affecting the character and progress of the next event. In short, the flow chart connects to "View of Nature Element as Symbol" as symbol with Useable Approach through the theory of Pengkaedahan Melayu can be seen in figure 1. Therefore, this article will be focusing towards nature element such as flora and fauna including paddy, Gondang Snails, fish and other element like air which is in this novel conveying a meaning or event. An overall research and analysis will be shown to support this further research.

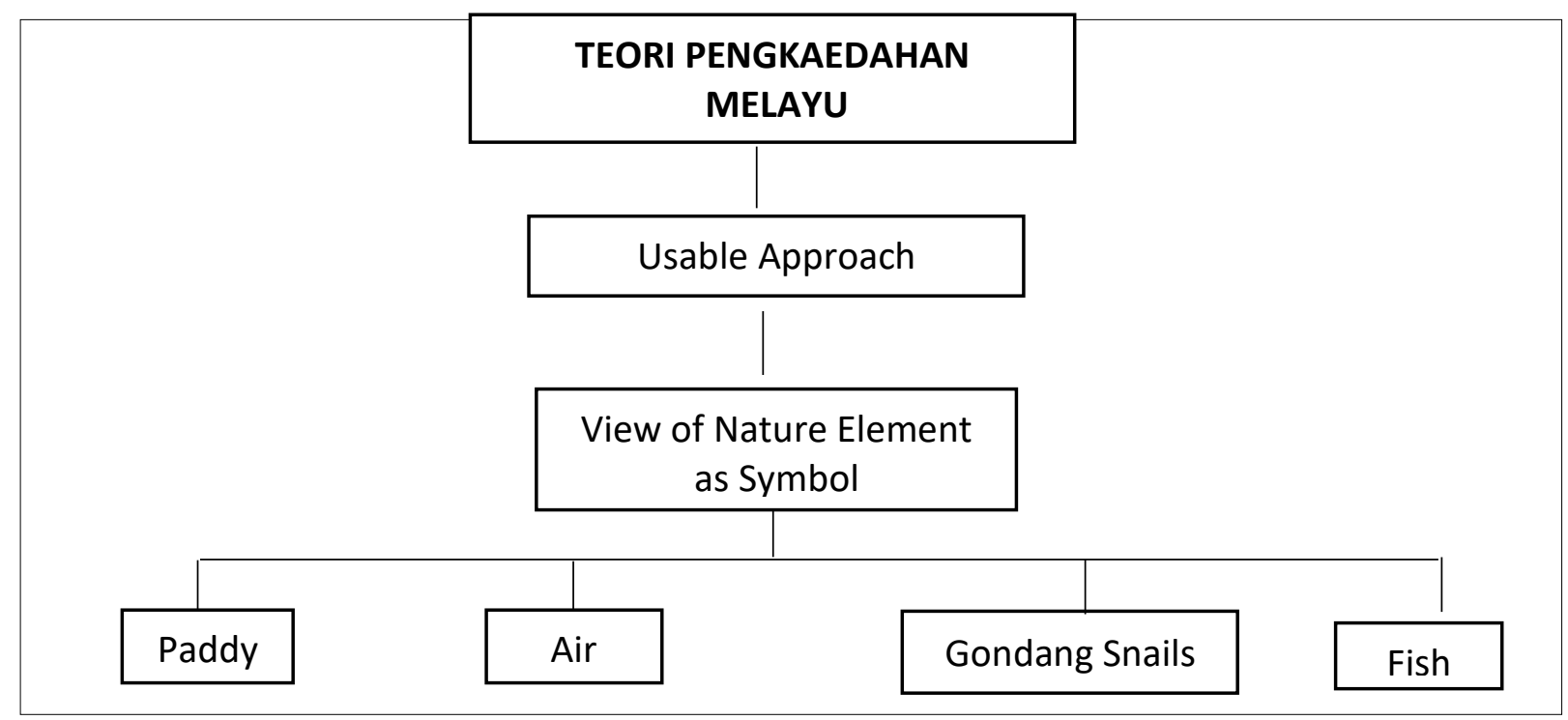

Figure 1: Useable Approach and View of Nature Element as Symbol in Theory of Pengkaedahan Melayu

\section{Analysis}

This novel revolves on the lives of village community endeavouring planting of paddy as their source of income. Cah as the main character in this novel is seen persistent in fighting their rights in for the sake of protecting the paddy plantation from taking over by the authorities for development purpose. Therefore, this research explores the nature element in seeing the alignment of braiding the novel and the research focus. Thus, the analysis framework used is Useable Approach which is in the theory of Pengkaedahan Melayu. So, through this context discussed, the nature element in this novel will be identified and analysed and interpretated 
in the meaning to fulfil this objective research. In this context, in showing the nature's element as a guide in interpreting an event or incident, this novel is peered in giving the concentration towards few nature elements. The element discuss in this research is paddy, air, fish and Gondang snail.

\section{Paddy}

In Malaysia, paddy is believed being planted since early century in Lembah Bujang, Kedah. Thus, planting of paddy structured since early 1664 when paddy was planted in the Straits of Sungai Korok, Kedah (Hamid, 2010). Paddy is an economy source and the main food supply in Malay community since centuries. Rice is the staple food for Malay community; therefore the nature element (paddy) is a tightly bonded with them.

In the Malay community tradition, the paddy element is known to be very meaningful (Shukor \& Marlina, 2016). The paddy element is considered sacred among the Malay community tradition. The Malay community is synonym with the nature element of symbolism paddy in conveying the meaning of figuratively and implied. This is because paddy is an economy source and the main food supply in Malay community since for centuries. In this context, the using of the symbolic object of paddy is usually used by author in revealing the meaning figuratively and implying. The implied element in the paddy symbolic is clearly stated in interpreting and next is a guide in mankind living. According to (Karim, 1993) the parable in the world of paddy agriculture is often used in literature and is proven that the perception and philosophy of the Malay community is affected by this activity. Aligning to this, the Malay community uses this symbol nature as paddy as a figurative language in explaining the income source, family relationship, good value moral and so on.

The usage of the paddy symbol is also used in the Malay proverb on low profile attitude. Symbolic of planting paddy is used because naturally the paddy is known to bow down during harvesting. This proverb shows the low profile of a person which needs to be implied in a man of knowledge and is not showing his greatness. Besides, the paddy symbol is connected in a family relationship. This is, paddy planting paddy can bond the ties of relationship between families and local community. This is supported by (Kadir, 1992) in saying that the activity of planting paddy gets to strengthen the relationship of traditional Malay community. Therefore, the using of the paddy symbol means important in the daily lives of the Malay community and is able to bring towards the building of good and harmony community.

Moving on, through this novel of Harga Sebuah Maruah (2007) the author shows the usage of nature element through the paddy symbol which is the character of Hijrah is being very happy when the paddy plantation bears fruit. The plantation worked on is fertile and is waiting to be harvested which will get a huge amount in return. Hijrah shows thankfulness to the Almighty for all the prayers fulfilled because of the return not only for him but for his family as well. This can be seen in the text below:

Therefore, its is because of that Hijrah is confident upon seeing the paddy trees bears fruit, stem and is bowing down, the end is yellowish and the leaves is drying to give way for the new stem growing.

(Abdullah, 2007: 289) 
Through this excerpt, the author describes the symbol of paddy fruiting. The paddy is fertile and yellowish. Is seen that the author is being focus on the paddy symbolic which means implying. The implied meaning that wants to be revealed is the source of income in the Malay community that endeavouring paddy plantation supports living. Also, paddy symbol manifests the spirit of the Malay community to be more persistent in bringing up the economy towards a better level. Clearly seen, interpreting literature valued based on perception of reader, when reader gets a benefit from the reading of literature than the literature is consider a success. The paddy symbol spoken by the author, shows implied meaning that gives exemplary and teaching to the reader. In this context, the author voices how an outcome of literature benefits and gives usage towards the living for human. Literature and nature element (paddy plantation) is seen by author manifesting thoughts and philosophy in Malay community. Aligning in this, it is align to Useable Approach which indicates that literature is an object that benefits and usage towards the lives of mankind.

Clearly shown, interpreting literature is valued by the readers perception by gaining benefits through the reading of literature therefore creating a literature is seen successful. Paddy symbolic seen by author has a lot of implied meaning which can give good exemplary to readers. In this context, author voices how a good literature brings out the good and useful towards living of mankind. Furthermore, literature and nature element (paddy) are seen by author as connection in manifesting thoughts and proverbs of Malay community. Aligning to this, is shown to be align towards Useable Approach which is a literature of an object which brings benefit and useful towards living.

\section{Air}

Air is a main element. Humans cannot live if there is not enough air. Air includes a mixture of few types of gas such as nitrogen, gas, molecules, carbon dioxide and other gas (Sulaiman, 2015). The need of clean gas is important in daily livings. Air provides oxygen which is very useful for mankind for breathing and for other relevant activities.

Subsequently, Malay community usually using this nature element in conveying something figuratively and implying. The symbol of air or wind is often use by the Malay community to convey something implying. One of the purposes of air or wind used is in translating feelings or background emotions. However, there are few situations and incident that happens in the community using this element. According to (Hanani, 2011) nature owns the meaning and proverbs of its own and creates symbol of useful symbolic for increasing the level of human life. Thus, symbol and symbolic allows readers to imagine and translate the situation and event happened.

A symbol or symbolic is not easy to translate of its meaning. Thus, Malay tradition community uses symbol as the nearest living for mankind such as nature element. According to (Hassan, 2021) symbol or symbolic used in conveying something has to be accepted by universal community. This is to make sure that a symbol is understandable and accepted by all that understands the rules of the particular symbol. So, a nature element used indirectly shows the thoroughly and sensitivity of Malay community towards nature. Regarding the proverb and symbol in conveying the figurative to educate and guide is written in al-Quran in surah Al-Ankabut verse 43 which means:

We site these examples for people, but no one understands them except the knowledgeable ones.

(Mushaf Tajwid with the translation to Malay, 2006: 33) 
Ibn Katsir (Basmeih, 2006) translates the verse above as there is no one that understands and ponder except knowledgeable people. This verse summatively explains that proverb conveying is to guide human to the way accepted by Allah SWT and is only understandable by few groups which is very high knowledgeable that can interpret a meaning behind the said proverb. Moving on, through the novel of Harga Sebuah Maruah (2007), the author shows the usage of nature element through symbol of air in the excerpt below:

The wind of paddy from west makes the leaves sway hitting each other and the sugar cane tree planted by Hijrah beside the house swerving left to right.

(Abdullah, 2007: 48)

Blowing wind from the paddy field makes the leaves from the trees surrounding Hijra's house swaying gracefully. The quiet and dark night makes Hijrah feels uncomfortable. Hijrah remembers the earlier incident at the paddy field when few government officers visited to discuss on the paddy field land owned by her family. In this context, the author uses symbolic air to convey the feeling and emotions of Hijrah which is restless. The mango leaves is as likely angry with the wind that is roughly hitting on each other. The blowing wind gets the sugar canes leaves to sway left and right. This description provides an imaginary of grief and sadness and to the readers. Clearly, author is using the symbolic element of wind to convey an incident happened. Using nature element by author to portray the conflict in the role of Hijrah in implying and symbolic. Also, the approach used by author in conveying saying on an incident or event happened using the approach of humble and gentle without hurting the knowledge of anyone.

Thus, the usage of the symbolic nature is not only functions to convey a situation or event during it happens but to highlight the thoughts of author in expressing figuratively and implying. In this context, author is seen creating a literature which is able to teach and guide mankind towards a good and better way. Following, this display an aligning with Useable Approach which says that literature is an object that bring benefits in humans live.

\section{Gondang Snails}

Pomacea canaliculate or known as Gondang snails is a pest for paddy. This pest usually attacks the paddy seed during planting. Gondang snails attack this new sprouting seed until its becomes paddy in less than $\mathbf{4 0}$ days. This snail is from South America is brought into this country in the early 1990s (Sahid et. al, 2014). Many ways has been used by the farmers to kill this pest but Gondang snail breeds fast even though plenty of method is used to kill them. This snail lays up to 8,000 eggs a year which makes it more difficult to kill them. Nevertheless, besides the physical and mechanical way in used in controlling, the manual way is also used for controlling this species from breeding. The manual method using papaya tree, jackfruit, cassava leaves and spinach is potentially used as a bait to attract this snail (Amzah \& Yahya, 2014).

Symbol or symbolic often use to understand texts. Using nature element as symbol is appropriate in the process of making the literature more quality, realistic and interesting to present to the readers. (Hasan, 2015). Therefore, to translate and parse a symbol or symboic needs to be studied throughly. Symbol in the text of literature is always acceptable and used since centuries. In this context, Gondang snail is a symbolic of symboling challenges and 
obstacles faced by a community. Other than that, using the nature element (Gondang snail) in this novel is potraying conflict faced by the villagers.

Hence, through this novel of Maruah (2207), author shows the using of nature element through the symbol of Gondang snail in the excerpt below:

The end of scattering, almost three Gondang snails is collected by Cah. Almost a handful of red snail eggs collected......Cah did not understand why this snails recently is getting too much. Many ways by Cah and farmers is done including scattering poison brand or pouring diesel oil mixing with kerosene.

(Abdullah, 2007: 48)

The attack of Gondang snails on Cah paddy fields makes her very angry. Many ways has been done to kill these snails but there is more to be seen on the fields. Cah effort has come to an end when all manuals done is still not controlling this snail. The quarrel with the authorities is still freshly heard in her mind. In this context, author is showing the conflict facing by Cah. The frequent attack by Gondang snail on the paddy fields is a never-ending problem faced by Cah. The symbolic of Gondang snail showing by the author is to never give up in whatever the situation is and every problem has a solution. Therefore, the author manages to provide a literature giving guide and teaching to the readers. Clearly states, the symbol of Gondang snails is conveyed more symbolically so that the readers will take it as a lesson from it.

Hence, this potrays the aligning of approach Useable Approach which explains that literature is an object that can bring benefit and useful in human lives. It is also known, this matches the approach of Useable Approach that states literature developed by the author give good benefit and thus it becomes an exemplary in human lives. This using of symbolic explains the thinking of author in conveying something figuratively and implying. In this context, the author is seen producing literature that manages to provide teaching and guidance.

\section{Fish}

According to Kamus Dewan Fourth Edition (2014) fish is a meaning of an a live animal in the water and breathes using its gills. Otherwise, (Kasdan et. al., 2016) states that fish is a type of animal which includes in the category of Pisces, back boned (including vertebrata), habitats in the water, breathes using its gills, moves and balances using fins and is cold bloded. According to research done by (Kasdan et. al., 2016) most fishes is in the Malay proverb example freshwater fish, river, swamp and lake. This is because of the occupation those days as fisherman and farmers.

Furthermore, Malay community tends to use fish symbol in conveying figurative meaning. The natural properties of fish are more relax and become an inspiration to Malay community on conveying an event or something more symbolic. Fish symbol is used in relaying something positively or negatively in daily living of human. Clearly, the ability of Malay community tradition is often associate with nature element and human living is seen wisdomly and thinkfully high to think outside the box.

On the living in the ocean (sea) is seen spoken in al-Quran in surah Al-Nahl verse 14 which means: 
He is the One who has subjugated the sea, so that you may eat fresh meat (fish) from it,

(Mushaf Tajwid with the translation to Malay, 2006: 46)

Ibn Katsir (in Abdullah Basmeih, 2006: 46) interprets the above that Allah SWT creates the ocean for mankind using and in it includes sea living (fish) as an income source for human. Fresh fish is a gift by Allah SWT to human to carry on live. Utterance on the using of nature element through fish symbol can be seen through the below excerpt:

In the ditch there are a few kiambang and kemeling tree. Once in a while, the water shakes when the fishes swim. In the ditch, there are fishes like sepat, haruan and puyu. Cah doesn't care, she just let the ditch be the world for the fishes.

(Abdullah, 2007: 4)

Cah observes how happily the fishes in the ditch. Occasionally, the shaking water pierces the ears. The fishes are freely moving around without any threat. The kiambang and kemeling tree that grows in the ditch is like blessing the fishes. Even though in the ditch are many types of fishes (sepat, haruan and puyu) they are seem living peacefully. In this context, author is seen trying to convey directly and indirectly through the fish symbol. In this context, natural properties of fish swimming freely portrays the living human life in peace and harmony even though stress with all kinds of problems. Furthermore, various fishes and plants in the ditch is meaning that in human life having types of character, attitude and shall live without fight and quarrel.

Hence, author focus in the aspect that readers should get some benefits and teaching through this literature. Is seen that this is aligning with the approach of Useable Approach that says literature created by author gives good benefits and becomes a guide in the human lives.

\section{Conclusion}

Through this research done, it is clearly stated that Useable Approach in the theory of Pengkaedahan Melayu is appropriate to absorb in the novel Harga Sebuah Maruah (2007) exploited by Azizi Haji Abdullah. Useable Approach is seen suitable in analysing the novels background of nature element because the theory used is able to show that literature as an object nature that exist and events having reasons that certain functions. Other than that, symbols of nature elements of paddy, wind, Gondang Snails and fish is clearly seen in the novel where it is a bigger meaning said. "View of Nature Element as Symbol" as symbol is seen suitable in analysing this novel which portrays nature element because of the story plot which is on the paddy plantation activity. Aligning to this Useable Approach which in the theory of Pengkaedahan Melayu by Hashim Awang is seen showing relevant element and composition made as an objective of this research. Hence, this approach is pointing towards the useful and literature welfare, good content aspect or points of welfare and morality. Furthermore, the persistent towards this theory is on the author showing similarity of authoring the contents and title. Through this approach also, is seen author is trying to convey something implying symbolicly. Therefore, Useable Approach absorbed in this novel researched is shown that literature is able to be a tool to give benefit to human living inner and outer. Thus, the novel that is assess through perspective theory of Pengkaedahan Melayu is very helpful towards 
the readers in understanding and finding the meaning figuratively and implying. Overall, Useable Approach is used in this novel.

\section{References}

Azizi, A. (2007). Harga Sebuah Maruah. Kuala Lumpur: Dewan Bahasa dan Pustaka.

Basmeih, A. S. (2006). Mushaf Tajwid Berserta Terjemahan ke dalam Bahasa Malaysia. Kuala Lumpur: Darul Fikir.

Badrulhadza, A., \& Hafizi, M. Y. (2014). Kawalan Siput Gondang di Sawah Menggunakan Umpan Penarik. Jurnal Teknologi (Sciences \& Engineering),70(6), 9-12

Chong, A. F. (2008). Kajian Terpilih Brunei Darussalam Dari Perspektif Pengkaedahan Melayu. Bandar Sri Begawan: Dewan Bahasa dan Pustaka Brunei.

Ghoffar, M. A. E. M., \& Abu Ihsan al-Atsari, A. I. (2004). Tafsir Ibnu Katsir Bogor: Pustaka Imam Asy Syafi'i. (Jilid 1-8).

Hashim, A. (2003). Sejarah Kesusasteraan Melayu Moden: Esei Kritikan. Kuala Lumpur: Dewan Bahasa dan Pustaka

Hafiz, M. I., S, Fhaisol, M. A., \& Khalisanni, K. (2014). Kandungan Pemakanan Siput Gondang. Buletin Teknologi MARDI, Bil.6 (2014): 99-105

Hashim, A. (1998). Teori dan kritikan kesusasteraan Melayu di Malaysia. Pangsura, 6 (4), 101115.

Jaafar, S. (2017). Unsur Alam Dan Masyarakat Dalam Teks Terjemahan Bahasa Melayu

Junaini, K., Hashimah, N. J., \& Nurasikin, W. I. (2016). Ikan (Pisces) dalam Peribahasa Melayu: Analisis Semantik Inkuisitif. International Journal of the Malay World and Civilisation (Iman), 4(1), 31 - 42

Junaini, K., \& Julaina, N. (2021). Padi dalam Peribahasa Melayu: Analisis Semantik. International Journal of the Malay World and Civilisation, 9(1), 59 - 72

Kamus Dewan (Edisi Keempat). (2015). Kuala Lumpur: Dewan Bahasa dan Pustaka.

Noraini, A. S. (2016). Padi Sebagai Tanda dalam Peribahasa Melayu. Jurnal Melayu, 15(1), 2649

Noraini, A. S., \& Marlina, T. I. (2016). Padi Sebagai Tanda dalam Peribahasa Melayu. Jurnal Melayu, 15(1), 26-49

Razman, F. S. (2015). Atmosfera Bumi dan Tindakbalas Kimia Pencemaran Udara. Dlm. Sharifah Norkhadijah Syed Ismail \& Mohd Armi Abu Samah (pnyt), Meneroka Interaksi Dinamik dalam Kesihatan Persekitaran (Exploring the Dynamic Interaction in Environmental Health). 1(1) (hlm.53-69)

Rahimah, A. H. (2010). Piama dan Petua Tradisi: Ilmu Menanam Padi Masyarakat Melayu di Utara Semenanjung Malaysia. Sari - International Journal of the Malay World and Civilisation. 28(2), 211 - 233211

Rusmawati, T. R. H. (2021). Alam dan Perlambangan dalam Cerpen S. Othman Kelantan. DIm. Wiyatmi, M.Hum, Novita Dewi, Mawar Safei (pnyt), Sastera Hijau di Indonesia dan Malaysia dalam Kajian Ekokritik dan Ekofeminis. (hlm. 311-327). Yogyakarta: Cantrik Pustaka.

Saadan, M., \& Zarrina, C. (2016). Konsep Alam menurut Daud al- Fatani dalam Karyanya Manhal Al- Safi: Analisis Dari Perspektif Astronomi Islam. Afkar, Vol. 18 Issue 2, 2-42

Safiah, N., K, \& Aishah, S. M. A. (1993). Unsur Padi dalam Pantun dalam Segemal Padi Sekunca Budi. Kuala Lumpur: Akademi Pengajian Melayu. Surah Ar-Rahman. International Journal of the Malay World and Civilization 5(3): 1-23. 
Silfia, H. (2011). Siti Zainon Ismail Mentafsir Roh Seni Budaya Dari Perspektif Tradisional dan Moden. Dewan Sastera. 41(11), 32-36

Abdul Kadir, W. Y. (1992). Urbanisasi dan Modenisasi Budaya Melayu. Kuala Lumpur, Malaysia: Akademi Pengajian Melayu.

Zaitun, H. (2015). Manifestasi Citra Alam dalam Novel Ombak Bukan Penghalang: Suatu Penelitian Firasat Melayu. Tesis Sarjana. Universiti Utara Malaysia. 